\title{
MORPHOMETRY OF THE POSITIONING OF CORTICAL TRAJECTORY PEDICLE SCREWS IN BRAZILIANS
}

\author{
MORFOMETRIA DO POSICIONAMENTO DE PARAFUSOS PEDICULARES DE TRAJETO \\ CORTICAL EM BRASILEIROS
}

\section{MORFOMETRÍA DEL POSICIONAMIENTO DE TORNILLOS PEDICULARES DE TRAYECTO CORTICAL EN BRASILEÑOS}

\author{
Fernando Magalhães Gosende, ${ }^{1,2}$ Rogério lúcio Chaves de Resende, ${ }^{1}$ Carlos Bauer Namem lopes Junior, ${ }^{2}$ Jefferson Soares Leal, ${ }^{1}$ Paula Silvelira Santana, ${ }^{2}$ \\ Ângelo Ribeiro Vaz de Faria, 1,2 Luiz Claudio de Moura França ${ }^{2}$ \\ 1. Hospital das Clinicas da Universidade Federal de Minas Gerais (HC-UFMG) Belo Horizonte, MG, Brazil. \\ 2. Rede Mater Dei, Department of Orthopedics. Belo Horizonte, MG, Brazil.
}

\begin{abstract}
Objective: Morphometric study of the positioning of the cortical trajectory pedicle screw in the lumbar spine of Brazilian patients of different sexes and ages, through the use of computed tomography images, in order to obtain more reliable data about cortical screw insertion and the variations observed, providing assistance for a safer, more effective approach with fewer complications. Methods: Selection of 100 patients from a database, alternating by sex, measuring the length, diameter, cephalic angulation, and lateral angulation of the vertebrae from L1 to L5. Results: Statistically significant measurements were obtained for the four different parameters in relation to sex. The mean age was 56, with a minimum of 20 and a maximum of 87 years. The $L 4$ and $L 5$ screws showed a reduction in relation to the other levels, while the width showed a progressive increase starting at L3. Lateral angulation was the parameter with the least variation among the levels, while there was greater variation and a reduction from L4 to L5 in cephalic angulation. Conclusion: Statistically significant results were obtained for length, diameter, lateral and cephalic angulation. Sex was a significant factor in spine surgery instrumentation using the cortical trajectory pedicle screw technique. Level of evidence I; Diagnostic study (investigation of an examination for diagnosis).
\end{abstract}

Keywords: Bone Screws; Spinal Fusion; Spine/surgery.

\section{RESUMO}

Objetivo: Estudo morfométrico do posicionamento de parafuso pedicular com trajeto cortical na coluna lombar de pacientes brasileiros de diferentes sexos e idades, por meio da utilização de imagens de tomografia computadorizada, com o intuito de se obter dados mais fidedignos em relação à inserção do parafuso cortical e às variações observadas, proporcionando assim subsídios para uma abordagem mais segura, eficaz e com menos complicações. Métodos: Seleção de 100 pacientes em bases de dados, com alternância de sexo, auferindo o comprimento, diâmetro, angulação cefálica e angulação lateral das vértebras de L1 à L5. Resultados: Foram obtidas medições com significância estatística em relação ao sexo nos quatro diferentes parâmetros mensurados. A média de idade foi de 56 anos, com mínima de 20 e máxima de 87 anos. Os parafusos de L4 e L5 mostraram redução em relação aos outros níveis, enquanto a largura se mostrou progressiva a partir de L3. A angulação lateral foi o parâmetro que apresentou a menor variância entre eles, ao contrário da angulação cefálica com maior variação e diminuição de L4 e L5. Conclusões: Foram obtidos resultados de comprimento, largura, angulação lateral e cefálica estatisticamente significativos. O sexo apresentou-se como fator significativo na instrumentação da cirurgia da coluna pela técnica do parafuso pedicular de trajeto cortical. Nível de evidência I; Estudo diagnóstico (investigação de um exame para diagnóstico).

Descritores: Parafusos Ósseos; Fusão Vertebral; Coluna Vertebral/cirurgia.

\section{RESUMEN}

Objetivo: Estudio morfométrico del posicionamiento de tornillo pedicular con trayecto cortical en la columna lumbar de pacientes brasileños de diferentes sexos y edades, mediante el uso de imágenes de tomografía computarizada, con el objetivo de obtener datos más fidedignos con relación a la inserción del tornillo cortical y a las variaciones observadas, proporcionando así subsidios para un abordaje más seguro, eficaz y con menos complicaciones. Métodos: Selección de 100 pacientes en bases de datos, con alternancia de sexo, midiendo la longitud, diámetro, angulación cefálica y angulación lateral de las vértebras desde L1 hacia L5. Resultados: Fueron obtenidas medidas con significancia estadística con relación al sexo en los cuatro diferentes parámetros medidos. El promedio de edad fue de 56 años, con edad mínima de 20 y máxima de 87 años. Los tornillos de L4 y L5 mostraron reducción con relación a los otros niveles, mientras que el ancho se mostró progresivo a partir de L3. La angulación lateral fue el parámetro que presentó la menor variancia entre ellos, al contrario de la angulación cefálica, con mayor variación y disminución de L4 y L5. Conclusiones: Fueron obtenidos parámetros de longitud, ancho, angulación lateral y cefálica estadísticamente significativos. El sexo se presentó como factor en la instrumentación de la cirugía de la columna por la técnica del tornillo pedicular de trayecto cortical. Nivel de evidencia I; Estudio Diagnóstico (investigación de un examen para diagnóstico).

Descriptores: Tornillos Óseos; Fusión Vertebral; Columna Vertebral/cirugía. 


\section{INTRODUCTION}

For several decades, fixation with pedicle screws has been the main technique used for stabilization of the lumbar spine in the treatment of lumbar spinal conditions such as fractures, tumors, and degenerative disease. ${ }^{1}$

The insertion of pedicle screws into the lumbar spine is performed through the pedicle, from the lateral to the medial, the point of insertion being located at the junction of the transverse process of the lumbar vertebra with the lateral wall of the upper facet of the vertebra to be fixed. ${ }^{2}$

Several potential complications are associated with this technique, such as dislocation of the screw and loss of stability, especially in patients with osteopenia or osteoporosis. ${ }^{3}$ Another disadvantage includes the significant muscle dissection necessary for the insertion of pedicle screws due to their lateral to medial trajectory ${ }^{3}$ and the risk of neural tissue injury. ${ }^{3,4}$

In the last decade, several advances have been achieved in the development of new screws and new insertion techniques, all seeking to optimize the biomechanical properties and/or minimize the risk of complications. ${ }^{5}$ Santoni et al. ${ }^{6}$ were the first to describe the cortical trajectory lumbar pedicle screw, known simply as the "cortical screw."

The cortical trajectory pedicle screw has its own placement, different from the classic pedicle screw. It has a caudal to cephalic path in the sagittal plane and medial to lateral path in the horizontal plane. Its idealization came from the challenge of performing instrumentation in patients with bone fragility resulting from osteoporotic disease. The objective was to create a screw path with greater contact with the cortical bone and, therefore, greater resistance to pullout.

Since then, numerous studies on this new technique have been conducted, demonstrating its characteristics and its potential benefits, comparing it directly with the classic pedicular technique.

This technique has been shown to be safe even for use in pediatric surgeries. ${ }^{7}$ Biomechanical studies have shown the advantages of this technique, including insertional torque superior to the traditional and lower incidence of overall complications. ${ }^{2,8,9}$ As regards functional improvement and pain, it is similar to the traditional technique in preliminary studies. 9,10

Cortical trajectory pedicle screw fixation can vary depending on factors, such as cephalic angulation and the size of the screw inside the lamina, as well as individual patient factors, such as bone density. Extensive anatomical knowledge is important for the placement of the lumbar fixation screw, since it can potentially offer better outcomes and fewer complications. Consequently, understanding the morphometric variability in the Brazilian population can enable a safer and more effective approach.

The objective of this study was to measure the morphometric placement parameters of pedicle screws inserted in the lumbar spines of Brazilian patients of different sexes and ages, in order to obtain more reliable data about cortical screw insertion and the variations observed, thus providing assistance for a safer and more effective approach with fewer complications.

\section{METHODS}

This was a retrospective study, submitted to and approved by the Institutional Review Board of the Hospital Mater Dei (identification number 04315318.0.0000.5128), in which we evaluated medical records and reviewed tomographic images. The participants of this study signed the Informed Consent Form.

We evaluated 100 computed tomography scans of the lumbar spine performed at the same institution: Rede Mater Dei de Saúde, Belo Horizonte, Minas Gerais. CT scans performed between 02/23/2018 and 11/21/2018 were included in the database for medical record review, 50 of which were of female patients and 50 of male patients. The exclusion criteria were fractured pedicles and pedicles with congenital alterations and other deformities.

The following measurements were taken: maximum length, maximum width in the axial plane, lateral angle in relation to the axial plane, and cephalic angle in relation to the sagittal plane. Alternately, the right or the left pedicles of the same lumbar spine were measured. All measurements were taken by the same radiology specialist in order to reduce the measurement bias and were based on the illustrations in Figures 1 and 2. The parameters described by Matsukawa et al. ${ }^{11}$ were used, with the point of insertion of the screw being the intersection of a line drawn in the median of the upper articular process of the vertebra and another perpendicular line located one millimeter caudal to the lower edge of the transverse process, as illustrated by the point in Figure 1.

The measurement data obtained were compiled in an Excel software table. For the statistical calculations, an exploratory analysis was first performed in order to determine the normality of the data. Quantitative variables were submitted to the D'Agostino-Pearson and Shapiro-Wilk normality tests. Following the normality tests, the median, the 25th and 75th percentiles (P25 and P75), and the minimum and maximum values of each of the variables were calculated.

An assessment of possible statistical differences between the different levels (L1 to L5) was conducted using the Kruskal-Wallis test, followed by Dunn's test of multiple comparisons. The MannWhitney test was used for the comparison of the measurements within each level in relation to the sex of the patient.

The research data were processed in the GraphpadPrism ${ }^{\circledR}$ version 5.0 for Windows statistical program and in all statistical tests a level of significance of $5 \%$ was considered. Thus, associations with a $p$ value less than 0.05 are statistically significant.

The measurements of pedicles with any kind of malformation, fractured vertebrae, or tumors were excluded from the calculations.

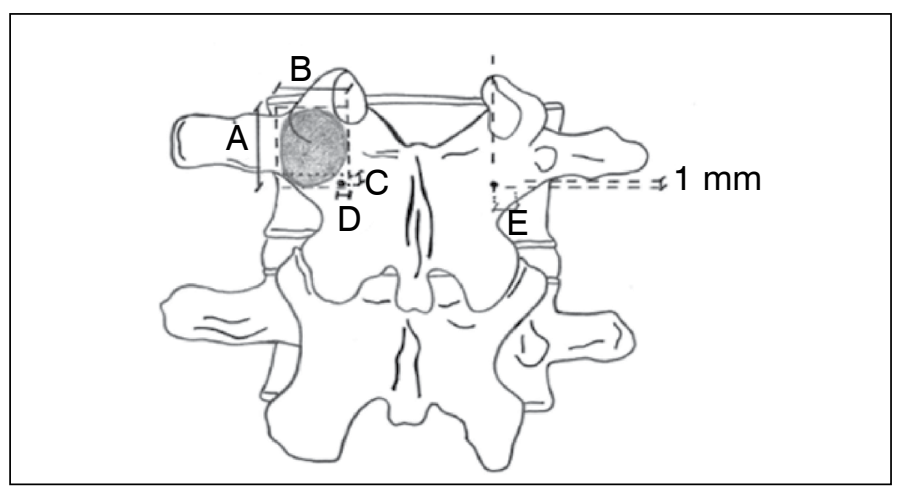

Figure 1. Point of insertion and pedicle measurements. (A) pedicular height, (B) pedicular width, (C) distance from the point of insertion to the lower edge of the pedicle, (D) distance from the point of insertion to the medial edge of the pedicle, and (E) point of screw insertion.

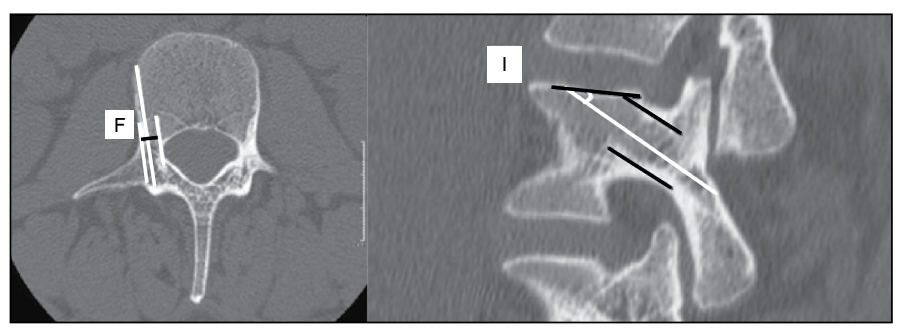

Figure 2. Illustration of a lumbar vertebra. (F) maximum diameter, $(G)$ maximum length, $(\mathrm{H})$ lateral angle, (I) cephalic angle of the screw in the sagittal plane.

\section{RESULTS}

The median age of the patients in this study $(n=100)$ was 56 years, with a minimum of 20 and a maximum of 87 years of age. The median age was similar between the sexes $(p=0.8496)$, with the median age of the female patients being 56 years (minimum of 20 and maximum of 87 years) and the median age of the male patients was 57 years (minimum of 25 and maximum of 86 years), as shown in Figure 3.

The median maximum bone lengths ( $L 1$ to $L 5$ ) of the total number of patients $(n=100)$ are shown in Figure 4 . The data obtained 
showed that there was no statistical variation between the median bone lengths of levels L1 to L3. However, there was a significant reduction in the $L 4$ and $L 5$ measurements $(p<0.0001)$ (Figure $4 A)$. The measurements taken at level $L 4$ of the lumbar spine were statistically lower than the measurements of levels $L 1, L 2$, and $L 3$ $(p<0.0001)$. Level $L 5$ had the lowest median bone length value as compared to the other levels $(p<0.0001)$. In relation to sex, both female and male patients presented this significant reduction in the bone length of levels $L 4$ and $L 5$ of the lumbar spine. In female patients, $L 4$ measurements were only lower than those of $L 2$, while L5 was statistically lower than all the other levels $(p<0.0001)$ (Figure $4 \mathrm{~B})$. Male patients presented the same statistical behavior as the total population: $L 4<L 1-L 3$ and L5 $<$ L1-L4 $(p<0.0001)$ (Figure $4 C$ ).

The maximum bone diameter of the total number of patients from levels $L 1$ to $L 5$ had the following median values: $L 1=6.46$ ( $\mathrm{min}$. 3.64 - $\max .12 .26), \mathrm{L} 2=6.64(\min .4 .51-\max .12 .35), \mathrm{L} 3=7.92$ (min. 5.28 - $\max .13 .26), L 4=10.08$ (min. 5.55 - $\max .14 .39)$, and $\mathrm{L} 5=13.72$ ( $\min .1 .86$ - max. 21.62) (Figure 5A). The median bone diameter was smaller at levels $\mathrm{L} 1$ and $\mathrm{L} 2$ and increased gradually to level $L 5$. There was a significant difference between all the pairs $(p<0.0001)$, except $L 1$ versus $L 2(p>0.05)$. As regards sex, both female and male patients showed this significant increase in bone diameter. In female patients, the same statistical behavior as in the total population was observed. In the male patients, in addition to the $L 1$ versus $L 2$ pair, the $L 1$ versus $L 3$ pair also showed no statistically significant difference $(p>0.05)$ (Figures 5B and 5C).

The lateral angulation of levels L1 to $L 5$ in relation to the sagittal axis presented the following median values: $L 1=10.72$ (min. 5.24 - $\max .19 .35), L 2=10.89(\min .4 .64$ - $\max .25 .02), L 3=11.84$ (min. 5.06 - max. 24.73), $L 4=12.41$ (min. $3.81-\max .30 .03)$, and $L 5=$ 12.46 (min. 5.12 - max. 28.25), without any significant differences among them (Figure 6A). When grouped by sex, this absence of significant difference was maintained among the female patients $(p>0.05)$, while there was a gradual significant increase observed among the males $(p=0.0165)$ when we compare the groups simultaneously. However, Dunn's test was not able to identify the specific pair related to the significant difference. (Figures $6 \mathrm{~B}$ and $6 \mathrm{C}$ )

The median cephalic angulation values for all the total number of patients at levels L1 to L5 were as follows: L1 $=25.02$ ( $\mathrm{min}$. 10.69 - $\max .43 .97), \mathrm{L} 2=22.22(\min .13 .35-\max .41 .74), \mathrm{L} 3=$ $22.27(\min .6 .76$ - $\max .38 .36), L 4=18.82(\min .6 .76$ - $\max .38 .36)$, and $L 5=18.45(\min .4 .74-\max .37 .31)$ (Figure $7 A)$. The data obtained showed no statistical variation in cephalic angulation between levels L1 to L3. However, there was a significant decrease in these measurements at levels $L 4$ and $L 5$ as compared to the higher levels $(\rho<0.0001)$, though this decrease was similar in both ( $L 4=L 5$, statistically). When analyzing by sex, among the females we observed a decrease in cephalic angulation at levels $L 4$ and $L 5$ only in relation to $L 1$, and at level $L 5$ also in relation to $L 2$ $(p<0.05)$. Among the males, $L 4$ presented a significant decrease when

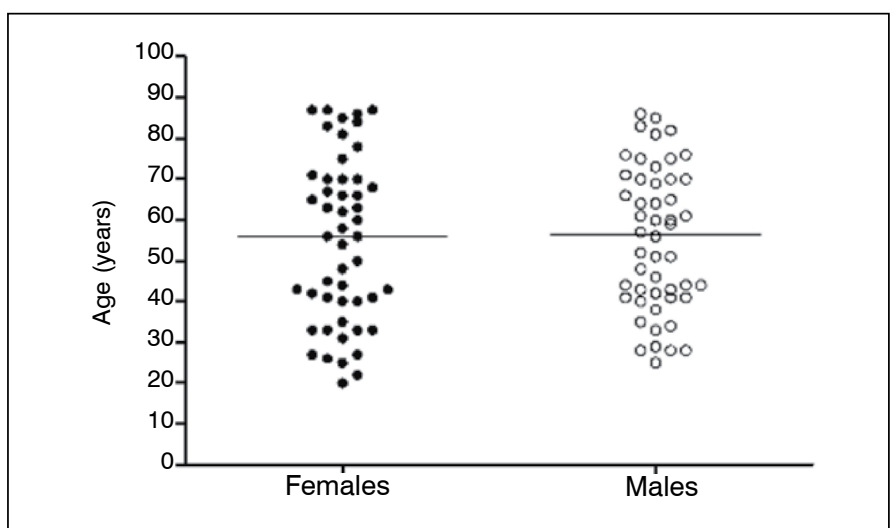

Figure 3. Distribution of patients by age (years) and sex (female and male). The ages of each of the 50 female and 50 male patients are represented. The horizontal lines indicate the median age of each group.

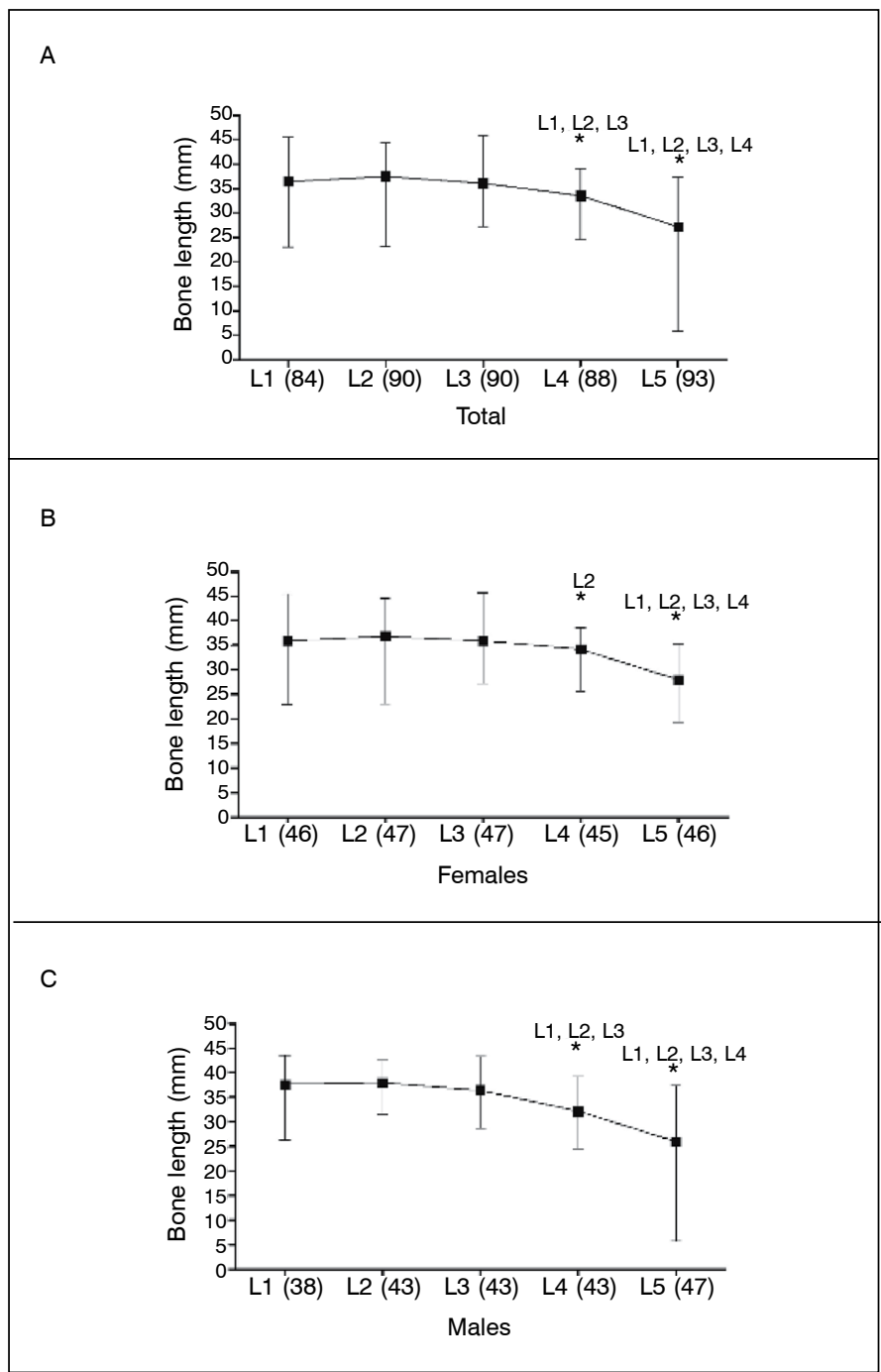

Figure 4. Maximum bone length $(\mathrm{mm})$ at each level $\mathrm{L} 1$ to $\mathrm{L} 5$ of the lumbar spine, represented by the median and minimum and maximum values: $(A)$ represents the total study population $(n=100)$, (B) the female population $(n=50)$, and (C) the male population $(n=50)$. The value in parentheses for each level indicates the number of tomographies analyzed after the exclusion of pedicles with some type of malformation, fractured vertebrae, and tumors.

compared to the lower levels $(p<0.05)$ and was similar to L5, which, in turn presented a significant decrease only in relation to $L 1$ and $L 3$ $(p<0.05)$. (Figures 7B and 7C)

In the comparison of the measurements between the sexes, we observed statistical differences between the bone lengths at levels L1 to $L 5$ between male and female patients $(p<0.05)$ (Table 1$)$. At level $\mathrm{L} 1$, median bone length was statistically greater in male patients than that observed in female patients $(37.67 \mathrm{~mm}$ versus $35.94 \mathrm{~mm}$, respectively) ( $p=0.0310)$. At level L5, median bone length was statistically greater in female patients $(27.97 \mathrm{~mm})$ than in male patients $(26.02$ $\mathrm{mm})(p=0.0333)$. The other levels did not present any significant changes in the comparison between the sexes $(p>0.05)$.

In turn, there were statistical differences between female and male patients in bone diameters of levels $L 1, L 2, L 3$, and $L 4$ $(p<0.05)$. At levels $L 1$ and $L 4$ the median bone diameter of male patients was statistically greater than that observed in female patients $(p \leq 0.0001)$. There was no significant difference at level L5 between the median bone diameter of female patients $(13.75 \mathrm{~mm})$ and that of male patients $(13.59 \mathrm{~mm})(p>0.05)$. (Table 1)

In the comparison of the relationship between lateral angulation and the sagittal axis at each level, there were statistical differences at all levels for both female and male patients $(\rho<0.0001)$ 


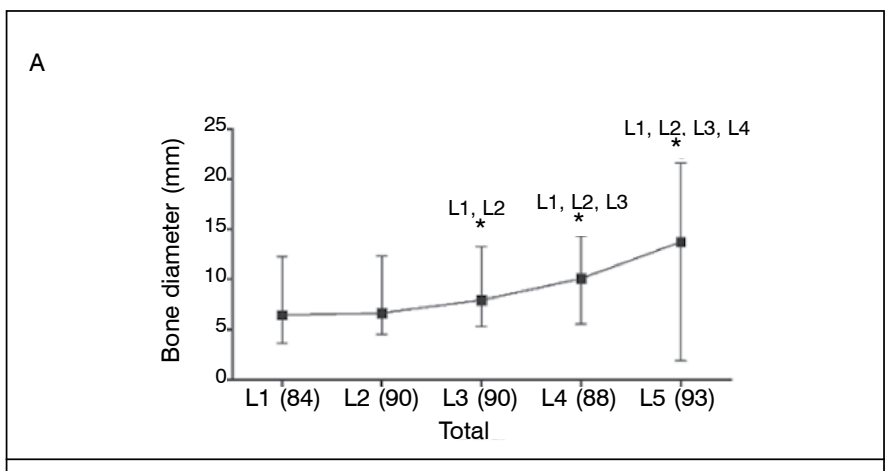

B

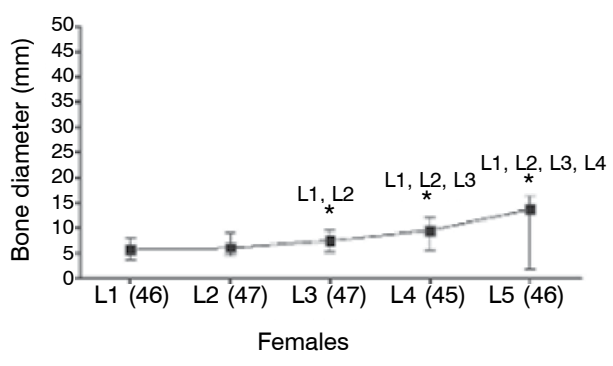

C

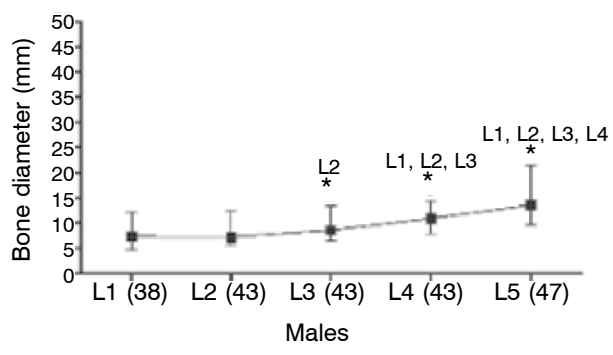

Figure 5. Bone diameter $(\mathrm{mm})$ at each level from $L 1$ to $L 5$ of the lumbar spine, represented by the median and minimum and maximum values: $(A)$ describes the total study population ( $n=100)$, (B) the female population $(n=50)$, and $(C)$ the male population $(n=50)$. The value in parentheses at each level indicates the number of tomographies analyzed after exclusion of the pedicles with some type of malformation, fractures vertebrae, and tumors.

(Table 1). In the comparison of the relationship between cephalic angulation and the horizontal axis at each level, the measurements of levels $L 1, L 2, L 3$, and $L 4$ were higher for females than for males $(p<0.05)$ (Table 1$)$.

\section{DISCUSSION}

The pedicle screw is currently the main method of choice for instrumentation in spinal surgeries, being considered the gold standard.

Since it was described by Santoni et al., ${ }^{6}$ several studies have been conducted supporting the use of cortical screws as a safe and biomechanically suitable alternative method for lumbar spine fixation. It is a less invasive technique of special biomechanical importance in osteoporotic bones.

If this study, we took morphometric measurements with the goal of observing the most reliable parameters for screw placement in the Brazilian population, taking sex into account in a sample with a broad age range. Recently Matsukawa et al. ${ }^{11}$ studied morphometric parameters through a review of 100 tomographies of predominantly male patients and with a mean age of 37 years. In our study, our random choice of patients of both sexes for inclusion in the calculations was aimed at complementing the limitation (single sex and little

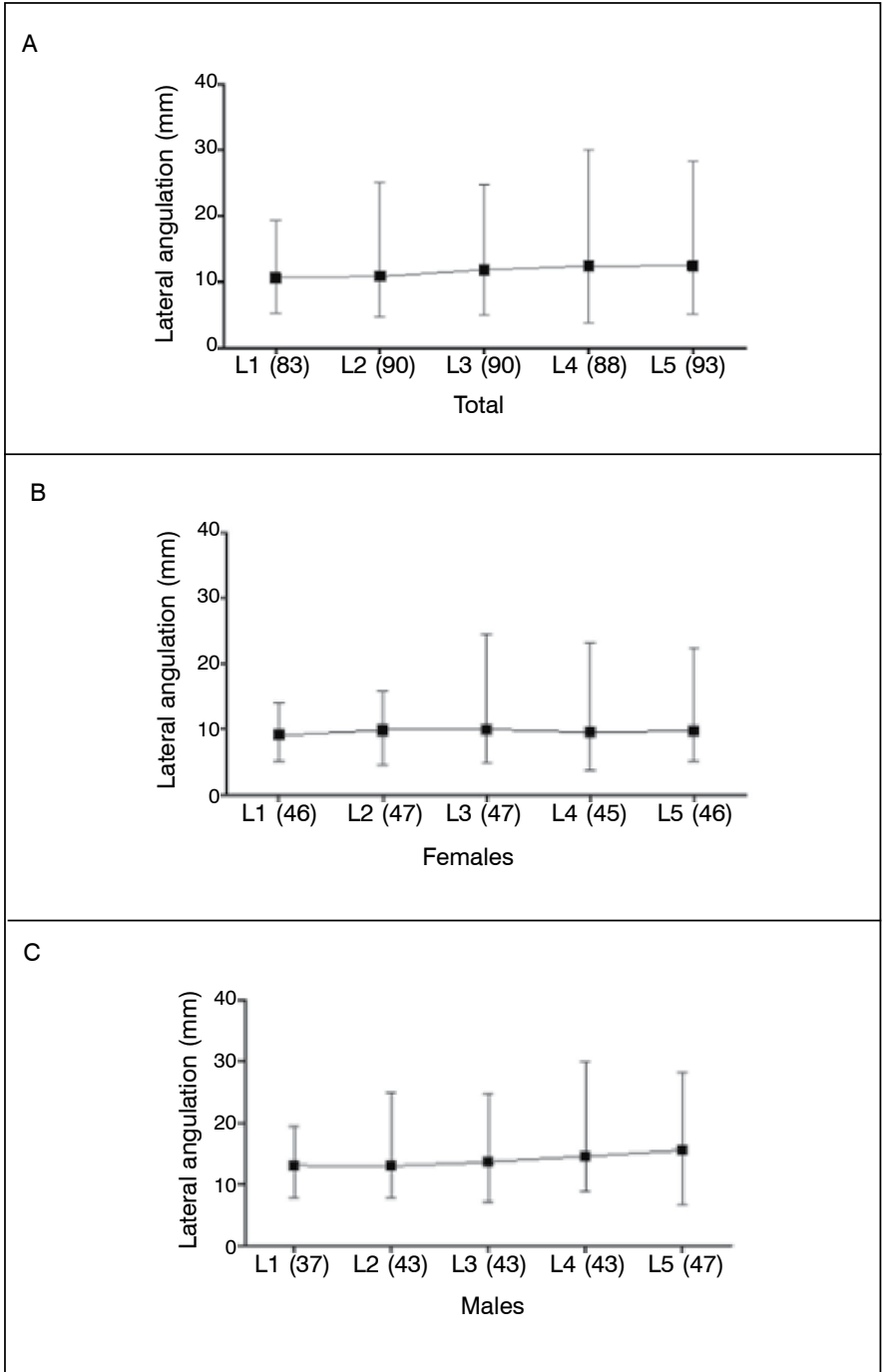

Figure 6. Lateral angulation $\left({ }^{\circ}\right)$ at each level from $L 1$ to $L 5$ of the lumbar spine, represented by the median and minimum and maximum values: $(A)$ represents the total study population ( $n=100)$, (B) the female population $(n=50)$, and (C) the male population $(n=50)$. The values in parentheses for each level indicates the number of tomographies analyzed following exclusion of pedicles with some type of malformation, fractured vertebrae, and tumors.

variation in age due to the military environment where the experiment was conducted) referred to by Matsukawa et al. ${ }^{11}$ in their conclusion.

Correct cortical screw placement through more targeted parameters helps to prevent complications. This study argues that there are four critical parameters that contribute to lumbar spine instrumentation.

Zhang et al. ${ }^{10}$ proposed a new point of screw insertion, using the lower instead of the upper facet as the bone reference. Unlike that used by Matsukawa et al. ${ }^{11}$ and the present study, Zhang et al. ${ }^{10}$ aimed for less destruction of the soft parts, attempting to keep the joint capsules whole. More recent parameters were again used by Senoglu et al. ${ }^{12}$ and Gao et al., ${ }^{13}$ both maintaining the point of insertion of Matsukawa et al. ${ }^{11}$

The length measurement results obtained for pedicles L1 to L3 were similar to those of Matsukawa et al., ${ }^{11}$ both in terms of the median values and the pattern of the ascending curve. The same, however, was not observed in relation to L4 and L5. Despite the similarities between the two studies, both with the curves descending from $L 4$ to $L 5$, the values obtained from our measurements were lower. Zhang et al. ${ }^{10}$ observed a similar pattern of growth from L1 to $L 3$ and an L5 length less than that of L4, but with lower values. Even though points of insertion were different, the outcomes of this study validated the results found by Zhang et al. ${ }^{10}$ and by Matsukawa et al. ${ }^{11}$ Senoglu et al. ${ }^{12}$ reported that in previous studies the lengths 


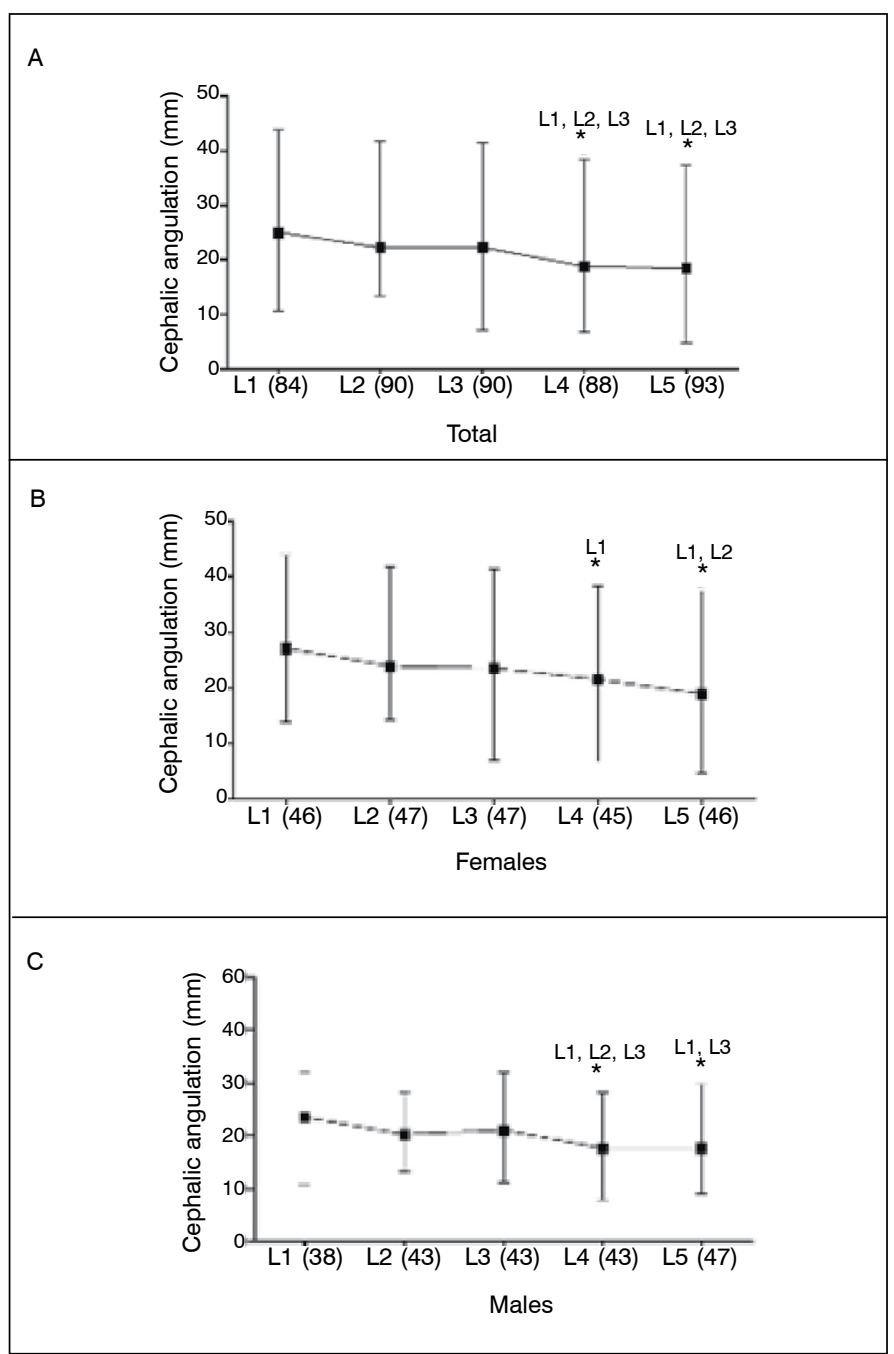

Figure 7. Cephalic angulation in relation to the horizontal plane $\left(^{\circ}\right)$ at each level from $L 1$ to $L 5$ of the lumbar spine, represented by the median and minimum and maximum values: $(A)$ represents the total study population $(n=100),(B)$ the female population $(n=50)$, and $(C)$ the male population $(n=50)$. The value in parentheses for each level indicates the number of tomographies analyzed following exclusion of pedicles with some type of malformation, fractured vertebrae, and tumors.

ranged from 30 to $35 \mathrm{~mm}$, at risk of violating the upper terminal plate, in concordance with our study.

Although not addressed in our study, Matsukawa et al. ${ }^{11}$ established cortical screw parameters for S1 insertion, with insertion at the junction of the center of the upper facet joint of $S 1$ and a point approximately $3 \mathrm{~mm}$ below the lowest point of the $L 5$ facet joint. Two years later, this information was contrasted by Zhang et al., ${ }^{10}$ who established the point of insertion as the junction of the medial border of the S1 pedicle and the lower border of the lower facet joint of $L 5$, reporting that it is closer to the upper plateau and therefore easier to see.

The differences in diameter observed corroborate the findings of Matsukawa et al., ${ }^{11}$ who reported differences in the same pairs of measurements as well as a gradual increase.

The lateral angulation results from the analysis of the tomographies of the total group corroborated the findings of Matsukawa et al. ${ }^{11}$ We observed a significant decrease in the cephalic angulation of $L 4$ and $L 5$ in relation to the other levels, which contradicts the findings of Matsukawa et al., ${ }^{11}$ who did not find any significant differences in the cephalic angulation in relation to the horizontal axis. The decrease would imply alterations in the positioning of the instrumentation in an attempt to prevent injury to the upper plateau.

The random choice of patients of both sexes to be submitted to the calculation was intended to exclude the limitation referred to by Matsukawa et al. ${ }^{11}$ in their conclusion, as their measurements were taken predominantly from male subjects with a mean age of 37 years (selection inside a military environment). Comparisons by sex with statistical significance were observed.

When we analyzed the differences between the sexes, we observed that in several measurements the male patients had values higher than those of the females, with the exception of vertebra $L 5$, where the female patients presented greater length and cephalic angulation, statistically significant when compared to L1 and L4. Level L5 presented the smallest difference between the sexes, where we observed statistical differences in the length and lateral angulation measurements. Such observations add information that assist the surgeon in the instrumentation of patients of both sexes.

Positive results were reported for the treatment of patients with spondylolisthesis using hybrid construction with proximal cortical screws and the conventional method at the caudal level. ${ }^{14}$ Zhang et al. ${ }^{10}$ cited the possible advantage of using it in obese patients due to the need for less dissection in these patients.

In a review conducted by Phan et al, ${ }^{15}$ the literature was still not completely cohesive in terms of results and complications when comparing the traditional pedicular screw approach with the cortical approach, which emphasizes the importance of conducting more studies addressing the cortical approach.

\section{CONCLUSION}

The parameters obtained in this study, still not documented for the Brazilian population, add information and serve as an aid to the surgeon in the instrumentation of patients of both sexes. The data obtained are based on statistical studies and the median values act as a suggestion for surgery, which must respect the steps of individual analysis and the variations in each patient during instrumentation.

This study is an attempt to improve spinal instrumentation techniques. As such, it used concrete data resulting from a scientific experiment that followed all the norms of academic research as a reference. However, a consensus still must be established around the best clinical and radiographical parameters for fabrication of the cortical screw so that the technique may become more applicable.

All authors declare no potential conflict of interest related to this article.

Table 1. Comparison of the median values of bone length $(\mathrm{mm})$, diameter $(\mathrm{mm})$, lateral angulation $\left({ }^{\circ}\right)$, and cephalic angulation $\left(^{\circ}\right)$ of each lumbar spinal level from L1 to L5 by sex of patient.

\begin{tabular}{|c|c|c|c|c|c|c|c|c|c|c|c|c|}
\hline Levels & \multicolumn{3}{|c|}{$\begin{array}{l}\text { Bone length } \\
(\mathrm{mm})\end{array}$} & \multicolumn{3}{|c|}{$\begin{array}{l}\text { Diameter } \\
(\mathrm{mm})\end{array}$} & \multicolumn{3}{|c|}{ Lateral angulation $\left({ }^{\circ}\right)$} & \multicolumn{3}{|c|}{ Cephalic angulation $\left({ }^{\circ}\right)$} \\
\hline L1 & 35.94 & 37.67 & $0.031 \mathrm{M}$ & 5.78 & 7.38 & $<0.0001^{\mathrm{M}}$ & 9.15 & 13.11 & $<0.0001^{M}$ & 27.13 & 23.57 & $0.0152^{M}$ \\
\hline L3 & 35.97 & 36.45 & $0.2165^{M}$ & 7.50 & 8.62 & $<0.0001^{\mathrm{M}}$ & 9.98 & 13.64 & $<0.0001^{\mathrm{M}}$ & 23.62 & 21.16 & $0.0263^{\mathrm{M}}$ \\
\hline L4 & 34.21 & 32.24 & $0.057^{\mathrm{M}}$ & 9.53 & 10.94 & $0.0001^{\mathrm{M}}$ & 9.58 & 14.59 & $<0.0001^{\mathrm{M}}$ & 21.58 & 17.78 & $0.0035^{\mathrm{M}}$ \\
\hline L5 & 27.97 & 26.02 & $0.033^{M}$ & 13.75 & 13.71 & $0.2960^{M}$ & 9.81 & 15.54 & $<0.0001^{\mathrm{M}}$ & 19.04 & 17.8 & $0.3750^{M}$ \\
\hline
\end{tabular}

$\mathrm{F}=$ female patients. $\mathrm{M}=$ male patients. ${ }^{\mathrm{M}}=$ Mann Whitney test adapted for comparison of non-parametric data . 
CONTRIBUTION OF THE AUTHORS: Each author made significant individual contributions to the manuscript. FMG, RLCR, LCMF, JSL, PSS, CBNLJ, ARVF: tabulation of data, review of the literature, writing and revision of the work.

\section{REFERENCES}

1. Phan K, Mobbs RJ. Systematic reviews and meta-analyses in spine surgery, neurosurgery and orthopedics: guidelines for the surgeon scientist. J Spine Surg. 2015:1(1):19-27.

2. Matsukawa $K$, Yato $Y$, Kato T, Imabayashi H, Asazuma T, Nemoto K. In vivo analysis of insertional torque during pedicle screwing using cortical bone trajectory technique. Spine (Phila Pa 1976). 2014;39(4):E240-5.

3. Mobbs RJ, Sivabalan P, Li J. Technique, challenges and indications for percutaneous pedicle screw fixation. J Clin Neurosci. 2011:18(6):741-9.

4. Rao PJ, Maharaj MM, Phan K, Lakshan Abeygunasekara M, Mobbs RJ. Indirect foraminal decompression after anterior lumbar interbody fusion: a prospective radiographic study using a new pedicle-to-pedicle technique. Spine J. 2015;15(5):817-24.

5. Sakaura H, Ohnishi A, Yamagishi A, Ohwada T. Early fusion status after posterior lumbar interbody fusion with cortical bone trajectory screw fixation: a comparison of titanium-coated polyetheretherketone cages and carbon polyetheretherketone cages. Asian Spine J. 2019;13(2):248-53.

6. Santoni BG, Hynes RA, McGilvray KC, Rodriguez-Canessa G, Lyons AS, Henson MA, et al. Cortical bone trajectory for lumbar pedicle screws. Spine J. 2009;9(5):366-73.

7. Sellin JN, Raskin JS, Staggers KA, Brayton A, Briceño V, Moreno AJ, et al. Feasibility and safety of using thoracic and lumbar cortical bone trajectory pedicle screws in spinal constructs in children: technical note. J Neurosurg Pediatr. 2018;21(2):190-6.

8. Hoffman H, Verhave B, Jalal MS, Beutler T, Galgano MA, Chin LS. Comparison of cortical bone trajectory screw placement using the midline lumbar fusion technique to traditional pedicle screws: a case-control study. Int J Spine Surg. 2019;13(1):33-8.
9. Chen $Y$, Deb S, Jabarkheel R, Pham L, Patel M, Singh H. Minimally invasive lumbar pedicle screw fixation using cortical bone trajectory: functional outcomes. Cureus. 2018;10(10):e3462.

10. Zhang H, Ajiboye RM, Shamie AN, Wu Q, Chen Q, Chen W. Morphometric measurement of the lumbosacral spine for minimally invasive cortical bone trajectory implant using computed tomography. Eur Spine J. 2016;25(3):870-6.

11. Matsukawa K, Yato $Y$, Nemoto O, Imabayashi H, Asazuma T, Nemoto K. Morphometric measurement of cortical bone trajectory for lumbar pedicle screw insertion using computed tomography. J Spinal Disord Tech. 2013;26(6):E248-53.

12. Senoglu M, Karadag A, Kinali B, Bozkurt B, Middlebrooks EH, Grande AW. Cortical bone trajectory screw for lumbar fixation: a quantitative anatomical and morphometric evaluation. World Neurosurg. 2017;103:694-701.

13. Gao H, Zhang R, Jia C, Xing T, Zhang J, Dong F, et al. Novel placement of cortical bone trajectory screws in the lumbar spine. A radiographic and cadaveric study. Clin Spine Surg. 2018;31(6):E329-36

14. Luther N, lorgulescu JB, Geannette C, Gebhard H, Saleh T, Tsiouris AJ, et al. Comparison of navigated versus non-navigated pedicle screw placement in 260 patients and 1434 screws: screw accuracy, screw size, and the complexity of surgery. J Spinal Disord Tech. 2015;28(5): E298-303.

15. Phan K, Ramachandran V, Tran TM, Shah KP, Fadhil M, Lackey A, et al. Systematic review of cortical bone trajectory versus pedicle screw techniques for lumbosacral spine fusion. J Spine Surg. 2017;3(4):679-88. 